\title{
Forms and Norms Matters Manufacturing Firms Corporate Social Responsibility /CSR/ Practices in East Gojjam Zone, Ethiopia
}

\author{
Getinet Fentahun ${ }^{1} \quad$ Yohannis G/Marriam ${ }^{2} \quad$ Dirgu Getinet $^{3}$ \\ Debre Markos University, College of Business and Economics, Management Department
}

\begin{abstract}
Ethiopia is one of the developing countries where the philosophy of corporate social responsibility is not well developed and also the governance system takes the form of mere control and decision making rather than encouraging development and implementation of a well-developed ethical code of conduct in the four spectrums. The main purpose of the study is focuses on to assessing forms and norms of manufacturing firm CSR practice in East Gojjam Zone. The study has realized in 13 higher manufacturing firms and 253 respondent stakeholders from the surrounding have been taken through descriptive study design. Primarily Questionnaire, interview, observation have used. Data have been analyzed by descriptive statistical tools by apply SPSS package. The results had shown us that there are no accepted forms and norms in external environment, Social and economy /context on the way organizations CSR operations in east Gojjam zone. Hence, the sympathy to the forms and norms of social responsibility in our case is still in its infant stage. The dilemma between the global standards and the local practices towards implementing CSR haven't been balanced. Generally, the study recommends that Prospectors \& Developers Association of Canada (2009) management system structure and requirements etoolkit must be applied.
\end{abstract}

Keywords: CSR, UN, Practices and East Gojjam Zones

DOI: $10.7176 / \mathrm{EJBM} / 12-10-02$

Publication date: April $30^{\text {th }} 2020$

\section{Back ground of the Study}

Carroll's four-part (economic, philanthropic, legal and ethical Responsibilities) pyramid construct can be useful to look at how CSR is manifested in a developing country context. Taking this approach, his contention is that the order of the CSR layers in developing countries, if this are taken as an indicator of the relative emphasis assigned to various responsibilities, differs from Carroll's classic pyramid(economic, legal, ethical and philanthropic responsibilities (Visser,2006). Hence, in developing countries, economic responsibilities still get the most emphasis. However, philanthropy is given second highest priority, followed by legal and then ethical responsibilities.

The new deoxyribonucleic acid of the business that contains the instructions a business needs to develop, sustain and restructure. These instructions are found inside every nation, and are passed down from country to their businesses. Also proposes a new interpretation on these terms. Like two intertwined strands of deoxyribonucleic acid, sustainability and responsibility can be thought of as different, yet complementary elements of CSR. Sustainability can be conceived as the destination-the challenges, vision, strategy and goals, i.e. what we are aiming for while responsibility is more about the journey - solutions, responses, management, actions, i.e. how we get there this implies an end and the means to that end respectively.

Public policy and public sector actors in middle and low-income countries are increasingly confronted with issues related to CSR. This study presents the range of opportunities that exist for them to mitigate negative impacts of CSR but also to harness its potential positive benefits for the public. Ethiopia is one of the developing countries where the philosophy of corporate social responsibility is not well developed and also the governance system takes the form of mere control and decision making rather than encouraging development and implementation of a well-developed ethical code of conduct in the four spectrums. However, currently, there are some good starts by some manufacturing industries but it has many problems in line with it. So this Study is focused on how these industries are practicing CSR.

\section{Statements of the Problem}

CSR issues in developing countries present themselves as dilemmas in the forms of: development versus environment, job creation versus higher labor standards, and strategic philanthropy versus political governance, which widely exercised in our case. Indeed in our country, CSR is rarely associated with Economic and philanthropy or charity, i.e. through corporate social investment in education, health, sports development, the environment, and other community services. But the remaining major pillars ethical and legal dimensions haven't been incorporating/ practicing under. These forms lead our nation, planet and economy towards development in partial positioning. 
Lacks of researched evidences on misbalance have been observing between organization and societal commitment in our region in general in east Gojjam zone in particular. Meaning organizations haven't scheduled any sort of activity in CSR practice. In the other way round, since the communities haven't any sort of gain from the institution the society get in the cultivation of hostility against it. This must in need formal ways of balancing the interactions through regulatory forms and cultivating positive norms in between the two. But there is no any responsible body to create such types of enabling environments.

The other issue may be highly tied with weak development and implementation of CSR factors analysis like the principles, laws, strategies and sustainability based practice that entails constantly working on improving the three P's (people, planet, and profit) in a balanced manner. This shows the social, environmental, economic aspect of the community. These weaknesses in our case highly manifested from the government.

Based on these the study answers the following questions:-

1. Did manufacturing firms have been exercising their production based on global forms?

2. What types of norms firms and the society have been practicing?

\section{Objectives of the Study}

\section{i. General Objective}

The general objective of the study is to asses' forms and norms of manufacturing firm CSR practice in East Gojjam Zone.

\section{ii. Specific Objectives}

Specific objectives of the study are:-

1. To view manufacturing firms have been exercising their production based on global forms

2. To scrutinize types of norms firms and the society have been practicing

\section{Research Methodology}

Methodology examines some of the research methods which may be necessary as back ground preparation to provide information for the research.

\subsection{Sample Selection}

According to Williams (2003) 'it is necessary to select a subsection of the elements from the population under consideration to make the research more manageable'. If this subsection is chosen following the correct principals it should be 'possible to draw inferences about the characteristics of the population on the basis of the statistics derived from the sample' (Brannick, 1997). In the case of the study have decided to take the total of 13 higher manufacturing firms in zonal administration.

\subsection{Sample Size Determination}

According to Kothari (2004) since Standard deviation is not known, the proportion is taken as equal of $50 \%$ for all target population groups. i.e., $\mathrm{p}=0.5$ and $\mathrm{q}=1-0.5=0.5$.

Based on this $\mathrm{n}=\frac{\mathrm{z}^{2} \mathrm{pq}}{\mathrm{e}^{2}}$

Where $\quad p=$ sample proportion, $q=1-p$

$z=$ the value of the standard variate at a given confidence level and to be worked out from table showing area under Normal Curve;

$e=$ precision rate/ the acceptable error $n=$ size of sample.

Therefore, $\mathrm{n}=\frac{(1.96)^{2 * 0.5 * 0.5}}{(0.05)^{2}}=\frac{3.8416 * 0.5 * 0.5}{0.0025}=385$ respondents

Method of determining the sample size is for each manufacturing firms selected based on conventional approach follows some "convention", number believed somehow to be the right sample size convincingly in the firm surrounding have taken from $\mathrm{n}$. The sampling technique have used could be considered judgmental sampling. Judgmental sampling is a non-probability sampling procedure 'that involves choosing persons based on judgment to act as respondents. The process is continued until the required sample size has been reached' (Robson, 2002).

\subsection{Selection of Research Method}

After the sample selections have completed a suitable research method have decided on. After taking into 
consideration the theoretical approach and the nature of the research objectives, descriptive approach with descriptive analysis using a pluralistic method/tools have used as the most suitable approach for analyzing the data.

\subsubsection{Data Type and Sources}

Sources of information are conveniently classified as either primary or secondary.

\subsubsection{Sources of Primary Data}

A structured questionnaire have used with the objective of gathering information on CSR practice from the surrounding community and owners/Managing directors. Interviews have conducted with illiterate stakeholders. Physical inspections around the plant and CSR practiced of the institution have carried out.

\subsubsection{Sources of Secondary Data}

Various publications, different journals, articles, reports, brochures, flyers, magazines' and documents of the company related to the subject under study, and other online materials have been utilized.

\subsection{Data Analysis}

Since the data have collected is on CSR Practice; which sets out initial findings in relation to the topic, and that general conclusions should be drawn from these by using descriptive(frequency, mean and Standard deviation).

\subsection{Reliability Analysis}

In order to examine the reliability of all scales in this study, we used different authors' instruments to assure the reliability. Cronbach's Alpha is the most commonly used statistic to measure internal consistency reliability of a scale (Pallant, 2016). The value is between 0 and 1, with 0 indicating no internal consistency and 1 perfect internal consistency reliability (Bryman and Bell, 2007). The value above 0.7 means acceptable, while the value above 0.8 means preferable. It the value is less than 0.7 , perhaps you may need to remove items with low itemtotal correlations. Corrected Item-Total Correlation values give you an indication of the degree to which each item correlates with the total score. Lower value which is less than 0.3 means that the item is something different from the scale as a whole (Pallant, 2016). All corrected item-total correlation values are positive and greater than 0.3. All the items correlate well with the total score. (0.793), (0.757), (0.797), and (0.795). Thus, almost all items indicate good internal consistency reliability in this sample and efficient internal reliability of all measurement items which stated in Chang (2017).

The constructs showed high internal consistency and reliability, with Cronbach alpha values of 0.79 for community CSR, 0.92 for environment CSR, 0.91 for employee CSR, 0.82 for consumer CSR, 0.87 for identification, 0.89 for commitment, and 0.87 for trust, all greater than the recommended value of 0.7 (Nunnally, 1978)

\subsection{Scope of the Study}

The study covers the perception, theory, and intervention of government, audit of CSR. However, this study have been concentrated on only practice of corporate social responsibility in "Corporate" which covers the large spectrum of businesses refers to higher manufacturing industries in East Gojjam Zone. In line with target population the community (residents, suppliers, clients, and employees), owners/managing directors, government officials/experts have included.

\subsection{Significance of the Study}

As the number of community demand rapidly growing within Ethiopia, the situation is believed to bring practice of CSR atmosphere among industries. This in turn presupposes continuous improvement which should be marked by responsible business operation that involves characteristics like economic, legal, ethical and philanthropic responsibilities. The study can direct those concerned or interested to make preparation to help the community of the country, especially those who are sharing to develop CSR implementation after finding out the gap. It also helps other researchers who want to conduct further study on the subject in the future. Generally, this study is of importance to:

* Policy makers who involve themselves in policy decisions matters for it is informative of what is going on in the Zone particularly in the Region generally,

* Educational and training institutions that need to impart knowledge on CSR and related issues,

* Industry stakeholders as the study offers information on the importance of having practice of CSR, and

* Academics and researchers in the area for future insight/stepping stone and references.

\section{Review of Literature}

\subsection{Background and Definition of CSR}

In practice views differ based on two factors. First, the extent to which importance is placed on the centrality of the financial business case for responsible business behavior in defining the scope of CSR practices i.e. the 
extent to which tangible benefits to companies must be demonstrable. Secondly, the extent to which government is seen to have a role in framing the agenda and how. A minimum standard for CSR might be that businesses fulfill their legal obligations or, if laws or enforcement are lacking, that they do no harm. A median approach goes beyond compliance, calling for businesses to do their best, where a business case can be made, to contribute positively to sustainable development by addressing their social and environmental impacts, and potentially also through social or community investments. Maximum standard points toward the active alignment of internal business goals with externally set societal goals those that support sustainable development.

According to Carroll (1999) there is an impressive history associated with the evolution of the concept and definition of corporate social responsibility (CSR). He traces the evolution of the CSR construct beginning in the 1950s, which marks the modern era of CSR. Definitions expanded during the 1960s and proliferated during the 1970s. In the 1980s, there were fewer new definitions, more empirical research, and alternative themes began to mature. These alternative themes included corporate social performance (CSP), stakeholder theory, and business ethics theory. In the 1990s, CSR continues to serve as a core construct but yields to or is transformed into alternative thematic frameworks. The concept of CSR has a long and varied history. It is possible to trace evidences of the business community's concern for society for centuries. Formal writing on social responsibility, however, is largely a product of the 20th century, especially the past 50 years. Furthermore, although it is possible to see footprints of CSR thought throughout the world mostly in developed countries.

According to Davis and Blomstrom (1966) social responsibility: refers to a person's obligation to consider the effects of his decisions and actions on the whole social system. Businessmen apply social responsibility when they consider the needs and interest of others who may be affected by business actions. In so doing, they look beyond their firm's narrow economic and technical interests.

According to Walton (1967), the new concept of social responsibility recognizes the intimacy of the relationships between the corporation and society and realizes that such relationships must be kept in mind by top managers as the corporation and the related groups pursue their respective goals.

In Johnson's (1971) a socially responsible firm is one whose managerial staff balances a multiplicity of interests. Instead of striving only for larger profits for its stockholders, a responsible enterprise also takes into account employees, suppliers, dealers, local communities, and the nation".

In 1980, Jones entered the CSR discussion with different perspectives. First, he defined CSR is the notion that corporations have an obligation to constituent groups in society other than stockholders and beyond that prescribed by law and union contract. Two facets of this definition are critical. First, the obligation must be voluntarily adopted; behavior influenced by the coercive forces of law or union contract is not voluntary. Second, the obligation is a broad one, extending beyond the traditional duty to shareholders to other societal groups such as customers, employees, suppliers, and neighboring communities.

CSR definition (Carroll, 1991). By this time, it is the discretionary component as philanthropic and suggesting that it embraced corporate citizenship. For CSR to be accepted by the conscientious business person, it should be framed in such a way that the entire range of business responsibilities is embraced. It is suggested here that four kinds of social responsibilities constitute total CSR: economic, legal, ethical and philanthropic. Furthermore, these four categories or components of CSR might be depicted as a pyramid. To be sure, all of these kinds of responsibilities have always existed to some extent, but it has only been in recent years that ethical and philanthropic functions have taken a significant place.

\subsection{Internationally Guiding Principles of CSR}

According to the ten principles of the UN global compact (2006) corporate sustainability starts with a company's value system and a principles-based approach to doing business. This means operating in ways that, at a minimum, meet fundamental responsibilities in the areas of human rights, labor, environment and anti-corruption. Responsible businesses enact the same values and principles wherever they have a presence, and know that good practices in one area do not offset harm in another. By incorporating the ten principles of the UN global compact into strategies, policies and procedures, and establishing a culture of integrity, companies are not only upholding their basic responsibilities to people and planet, but also setting the stage for long-term success. The ten principles of the United Nations global compact are derived from: the universal declaration of human rights, the International Labor Organization's Declaration on fundamental principles and rights at work, the Rio declaration on environment and development, and the United Nations convention against corruption.

Human Rights: - Principle 1: Businesses should support and respect the protection of internationally proclaimed human rights; and

Principle 2: make sure that they are not complicit in human rights abuses.

Labor: - Principle 3: Businesses should uphold the freedom of association and the effective recognition of the right to collective bargaining;

Principle 4: the elimination of all forms of forced and compulsory labor;

Principle 5: the effective abolition of child labor; and 
Principle 6: the elimination of discrimination in respect of employment and occupation.

Environment: - Principle 7: Businesses should support a precautionary approach to environmental challenges; Principle 8: undertake initiatives to promote greater environmental responsibility; and

Principle 9: encourage the development and diffusion of environmentally friendly technologies.

Anti-Corruption:- Principle 10: Businesses should work against corruption in all its forms, including extortion and bribery.

In the other ways round as cited in different literatures there are codes \& standards for CSR. These are:-

1. Global Reporting Initiative (GRI): GRI has been addressing the need for standardized approach to corporate sustainability reporting. In 2006, GRI published Version 3.0(G3) of its Sustainability Reporting Guidelines emphasizing performance indicators, which contain a separate section titled "Human Rights" with nine performance indicators. It is an international, multi-stakeholder effort to create a common framework for voluntary reporting of the economic, environmental and social impact of organizational activities. Its mission is to improve the comparability and credibility of sustainability reporting worldwide.

2. Social Accountability 8000: SA $8000: 2014^{e e}$ standard for social accountability, created in 2000 by Council on Economic Priorities Accreditation Agency (CEPAA). The SA 8000 code of practice is broken down into nine key areas child labor, management systems, working hours, compensation, disciplinary practices, forced labor, health \& safety, freedom of association \& collective bargaining and discrimination.

3. International Organization for Standardization (ISO) 26000: ISO an International Standard setting body has developed a new standard on Social Responsibility namely ISO 26000. ISO 26000 is intended for use by all types of organizations and in all countries and to assist organizations to operate in a socially responsible manner. According to ISO 26000, there are seven fundamental subjects of CSR as follows:-

Environment, Labor practices, Human rights, Organizational governance, Fair operating practice, Consumer issues, and Social development.

4. Occupational Health \& Safety Advisory Services (OHSAS) Standard: OHSAS 18001:2007 is applicable to any organization which aims to establish a health and safety management system at work.

5. Organization for Economic Co-operation and Development (OECD) guidelines for multinational companies: OECD guidelines contains recommendations on core labor, environmental standards, human rights, competition, taxation, science and Technology combating corruption and safe guarding, consumer rights. These guidelines acknowledge and encourage the contribution that MNEs can make to local capacity building as a result of their activities in local communities (OECD, 2011).

6. Others: ISO 9001:2000 (quality) and ISO 14001:2015 (environment) are generic management system standards $^{e e}$, so that the same standard can be applied to any organization, large or small, whatever its product or service.

\subsection{CSR Global Norms and Developing Country Industry Forms}

There is increasing evidence that CSR is emerging as a management issue within every business firm. The main drivers of this movement include increment of society awareness domestic political will, and international pressure. However, what is less understood is the nature of the shaping of CSR. As a concept, CSR has been widely interpreted as the way companies take into account interests of a broader range of stakeholders beyond owners and shareholders of the firm. Hence, it is about the way firms develop policies and practices to minimize the negative impacts and even increase the positive impacts of their business practices on various stakeholder groups.

In a Western context, the rationale for CSR has been explained as a result of interaction between business, government and society where institutional pressures that develop from these interactions lead to certain expectations regarding the nature of business practices. This is where firms increasingly see CSR as a strategic approach to maintaining and enhancing legitimacy and reputation so as to ensure the buy-in and loyalty of key stakeholder groups such as employees and customers. Next to this more instrumental view, it has also been identified that firms can have more normative motives for CSR seeing it as the right thing to do. Do the latter rationales apply to the Ethiopian context? This topical issue aims to shed some light on the nature of CSR in Ethiopia and to identify key elements of the direction that CSR in Ethiopia is moving. Particular focus will be placed on how CSR is being shaped in Ethiopia in general and Amhara in particular through the interaction of business with a variety of stakeholders, including government, employees and societal groups. From a business perspective, the definition of stakeholder places the firm in the center of analysis and refers to any group or individual who can affect or is affected by the achievement of the firms' objectives (Freeman, 1984). Thus, a group or individual could represent employees, shareholders, customers, suppliers, governments, communities, media, competitors, analysts, trade unions, NGOs and the general public ( $\mathrm{Su}, 2007)$.

Emerging actors, evolving CSR While the companies' approach towards CSR is mainly reactive to changing domestic circumstances and global demands, the Ethiopian government's push for CSR is confined to enacting legislation; however, implementation and enforcement have been relatively lax (Sarkis \&etal, 2011). 
This is mainly attributed to the decentralized system of governance in Ethiopia, where the central government delegates implementation and enforcement authority to the regional and local governments. But a local bureaucrat's performance is mainly assessed by the central government based on whether s/he reaches the economic targets. Thus, the undervaluation of the social and environmental well-being in the assessment may lessen the priority given to CSR, as well as that given to social, economic and environmental protection. The main form of the government regulations couldn't encourage and promoted the uptake of CSR by Ethiopian firms, actual implementation still relies on the voluntary will of businesses. The government has also prevented Non-Governmental Organizations from growing too big and powerful. Finally, Non-Governmental Organizations do not have any ability to raise funds rather act as an extra set of eyes and ears for the government.

\section{Data Analysis and Discussion}

This chapter presents analysis, interpretation, findings and discussions of information collected from Stakeholders of Manufacturing firms in East Gojjam Zone. Three Hundred Eighty Five (385) questionnaires were distributed to these stakeholders and $65.714 \%$ of them were collected back. In the study, manufacturing firms corporate social responsibility practices in East Gojjam zone, 253 stakeholders participated with the objective of assessing manufacturing firms corporate social responsibility practices in East Gojjam zone. The data collected from this study were analyzed by using multiple methods, using the Statistical Package for the Social Sciences software. The responses of the stakeholders are summarized as follows:

Table 1:-Mean score measurement for the following mean analysis ${ }^{1}$

\begin{tabular}{|l|l|}
\hline Mean score & Description \\
\hline$<3.39$ & Low \\
\hline $3.40-3.79$ & Moderate \\
\hline$>3.80$ & High \\
\hline
\end{tabular}

Table 2:- Carroll's four part pyramid constructs in developing country context across influence up on economic, social and environmental factors.

\begin{tabular}{|c|c|c|c|c|c|}
\hline & & $\begin{array}{c}\text { Economic } \\
\text { Responsibilities }\end{array}$ & $\begin{array}{c}\text { Philanthropic } \\
\text { Responsibilities }\end{array}$ & $\begin{array}{c}\text { Legal } \\
\text { Responsibilities }\end{array}$ & $\begin{array}{c}\text { Ethical } \\
\text { Responsibilities }\end{array}$ \\
\hline Profit & Mean & 2.68 & 2.74 & 2.75 & 2.70 \\
\hline & $\mathrm{N}$ & 26 & 26 & 26 & 26 \\
\hline & Std. Deviation & 0.725 & 0.515 & 0.732 & 0.751 \\
\hline People & Mean & 3.10 & 2.92 & 3.06 & 2.88 \\
\hline & $\mathrm{N}$ & 152 & 152 & 152 & 152 \\
\hline & Std. Deviation & 0.697 & 0.56 & 0.712 & 0.659 \\
\hline Planet & Mean & 3.24 & 3.04 & 3.18 & 3.07 \\
\hline & $\mathrm{N}$ & 75 & 75 & 75 & 75 \\
\hline & Std. Deviation & 0.618 & 0.615 & 0.693 & 0.559 \\
\hline Total & Mean & 3.11 & 2.94 & 3.07 & 2.93 \\
\hline & $\mathrm{N}$ & 253 & 253 & 253 & 253 \\
\hline & Std. Deviation & 0.689 & 0.662 & 0.709 & 0.645 \\
\hline
\end{tabular}

From the above table implication the mean score is $<3.39$ we can understand that across all level of CSR construct group every respondent have low understanding about profit influence up on CSR constructs. Even though it is real we can specify which influencer (Profit, people, planet) is highly involved in which construct category by comparing the means. Therefore, respondents have great perception up on the influence of planet at each CSR constructs in developing nation (mean=3.24, 3.04, 3.18, 3.07 respectively) in a relative sense. This shows high impact up on manufacturing firms CSR outcomes, even though it is below average mean standard. In turn in the given table below (table 6) shows each construct influence up on economy, Social and the environment influence. In relative with their dimension as shown in the result companies which have been running in line with economic responsibilities have achieved their profit economy better than other factors. Responsibilities in relation with philanthropic act a lot contribute to preserve the social life. In regard with legal and ethical dimensions of the constructs economy and planet conservation respectively could considered as their deal. But in general it can be considered as low in creating great instruction between responsibilities and the economy, Social and environmental existences. These harshly affect the sustainability of the firms by creating

\footnotetext{
${ }^{1}$ From Zaidatol Akmaliah Lope Pihie and Afsaneh Bagheri
} 
comprehensive and strong bondage between the firm and stakeholders.

The study by Sultan (2016) shown CSR has no significant on profitability, which was forwarded to the staff of oil companies who participated in the group discussion and 33\%, 59\%, 8\%, 0\%, and $0 \%$ responded strongly agree, agree, and undecided, disagree, and strongly disagree respectively indicating agreement to the proposition that CSR has no significant impact on profitability of their company. The result is inconsistent with our finding that shown us each dimension of CSR constructs have a strong significant contribution up on the other.

Table 3:- Carroll's four part pyramid constructs/CSR in developing country context based on gender

\begin{tabular}{|c|c|c|c|c|c|}
\hline \multicolumn{2}{|c|}{ Gender of Respondent } & $\begin{array}{l}\text { Economic } \\
\text { Responsibilities }\end{array}$ & $\begin{array}{l}\text { Philanthropic } \\
\text { Responsibilities }\end{array}$ & $\begin{array}{l}\text { Legal } \\
\text { Responsibilities }\end{array}$ & $\begin{array}{l}\text { Ethical } \\
\text { Responsibilities }\end{array}$ \\
\hline \multirow[t]{3}{*}{ Male } & Mean & 3.16 & 2.95 & 3.13 & 2.94 \\
\hline & $\mathrm{N}$ & 206 & 206 & 206 & 206 \\
\hline & Std. Deviation & 0.619 & 0.542 & 0.658 & 0.602 \\
\hline \multirow[t]{3}{*}{ Female } & Mean & 2.50 & 2.92 & 2.92 & 2.91 \\
\hline & $\mathrm{N}$ & 47 & 47 & 47 & 47 \\
\hline & Std. Deviation & 0.826 & 0.646 & 0.802 & 0.743 \\
\hline \multirow[t]{3}{*}{ Total } & Mean & 3.11 & 2.94 & 3.07 & 2.93 \\
\hline & $\mathrm{N}$ & 253 & 253 & 253 & 253 \\
\hline & Std. Deviation & 0.689 & 0.574 & 0.709 & 0.645 \\
\hline
\end{tabular}

The whole over figure in the above table shows that both males and females have low attitudinal orientation across four constructs similarly. Even though the result shown is low attitude orientation for these constructs for comparison purpose we can see each dimension with in being male or female. From the table we can depict that males have higher attitudinal orientation than females in CSR activities. Both of them are higher in results of Pursuing better economic responsibility. The figures in the table shown that both males and females are lower in enforcing the firm to be responsible in ethical regards of Manufacturing firms (mean=2.94, mean=2.91 respectively) than other CSR constructs.

Table 4:- Stakeholders orientations on CSR constructs

\begin{tabular}{|l|c|r|r|}
\hline CSR constructs & $\mathrm{N}$ & Mean & Std. Deviation \\
\hline Economic Responsibilities & 253 & 3.11 & 0.689 \\
\hline Philanthropic Responsibilities & 253 & 2.94 & 0.574 \\
\hline Legal Responsibilities & 253 & 3.07 & 0.709 \\
\hline Ethical Responsibilities & 253 & 2.93 & 0.645 \\
\hline
\end{tabular}

The above table illustrates that Economic Responsibilities (mean=3.11, S.D=0.689), Philanthropic Responsibilities (mean=2.94, S.D=0.574), Legal Responsibilities (mean=3.07, S.D=0.709), Ethical Responsibilities (mean=2.93, S.D=0.645). This shows the mean score of all items is $<3.39$ this implies that a general perception of Stakeholders is low on all items measuring CSR practices and exercises of every company may not be divulge for stakeholders.

According to Merel (2013) study in Senegal shown us there is the strongest focus of the CSR practices of companies on their employees $(\mathrm{M}=4.50, \mathrm{SD}=0.43)$. Clients $(\mathrm{M}=4.29, \mathrm{SD}=0.38)$ and shareholders and investors $(\mathrm{M}=4.17, \mathrm{SD}=0.52)$ are important focus areas as well. With a mean of $3.37(\mathrm{SD}=0.78)$ surrounding communities make up the stakeholder group that receives the least focus. The environment $(\mathrm{M}=3.87, \mathrm{SD}=0.66)$ and suppliers $(\mathrm{M}=3.70, \mathrm{SD}=0.42)$ are focus areas as well, but get less attention than employees, clients and shareholders and investors do.

His study focus on different stakeholder groups of CSR practices Employees are thus the most important stakeholder group when it comes to CSR activities. This result is in line with the findings of the importance of the different stakeholder groups in CSR policies, where employees turned out to be a very important stakeholder group as well. Respondents explained that their employees are an important focus area because they are the heart of the company and without them the company will not be able to run its business. The companies also have a strong focus on its clients in their CSR practices. So even though about $50 \%$ of the companies indicated that their clients are a less important stakeholder group in their CSR policy, the CSR activities of the companies still focus quite strongly on its clients. In line with the importance given to shareholders and investors in the company's CSR policies, the companies also scored relatively high on the CSR practices statements related to its shareholders and investors. When asked about the importance of the environment in their CSR policy, $44 \%$ of the companies indicated that it is a very important issue. Reasons given for this were that without taking the environment into account, the companies could, in the long run, probably not sustain their business activities. However, with a mean of 3.87, the environment is given less attention in their CSR practices than the three stakeholder groups discussed above. Of the 6 stakeholder groups, the least attention is given to suppliers and the 
surrounding communities of the companies. For suppliers, these findings are in line with the importance that is given to them in the company's CSR policies. However, even though about 50\% of the companies indicated that surrounding communities play a very important or important role in their CSR policies, this stakeholder group has the lowest score for the CSR activities of the companies.

Inconsistently, our result revealed that stakeholders haven't any strong orientation and interaction of CSR practicing in our case.

As coined by Aviva (2008) in three models of corporate social responsibility: interrelationships between theory, research, and practice Rather than articulating a set of principles that purports to offer necessary and sufficient conditions for CSR, this article focuses on the conceptual structure of CSR and the relations between its elements as depicted in three different schematic descriptions: pyramid, intersecting circles, and concentric circles. The pyramid shown hierarchy of separate responsibilities, the intersecting circle displays nonhierarchical sets of intersecting responsibilities and the concentric circles Integration of responsibilities; all sharing a central core. This is going in line with our result which shows greater interrelation between the components with their classification and factor analysis (economic, social and environmental).

\section{(a) Pyramid}

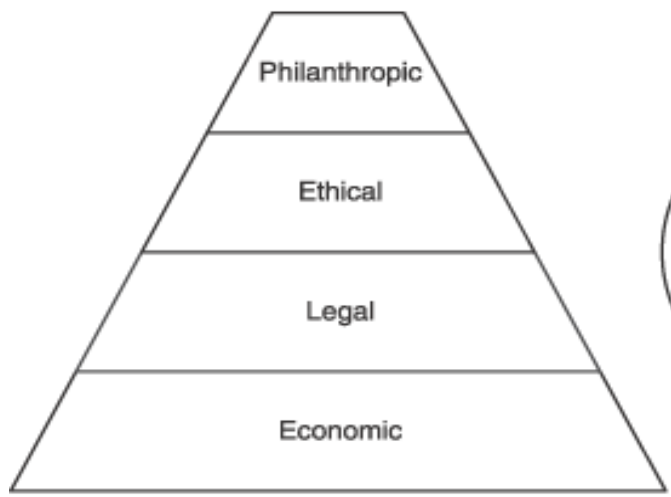

(b) Intersecting Circles

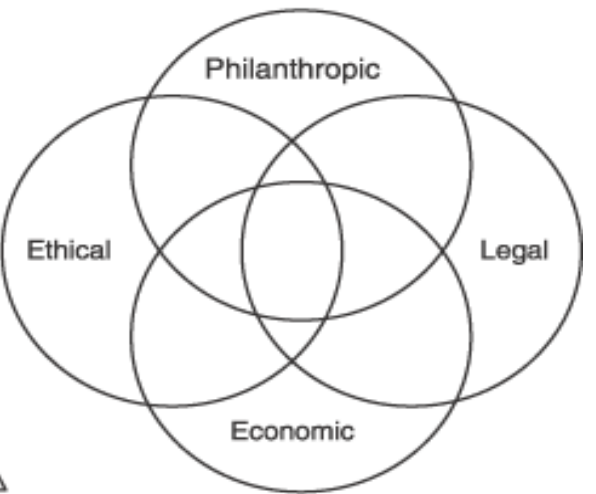

(c) Concentric Circles

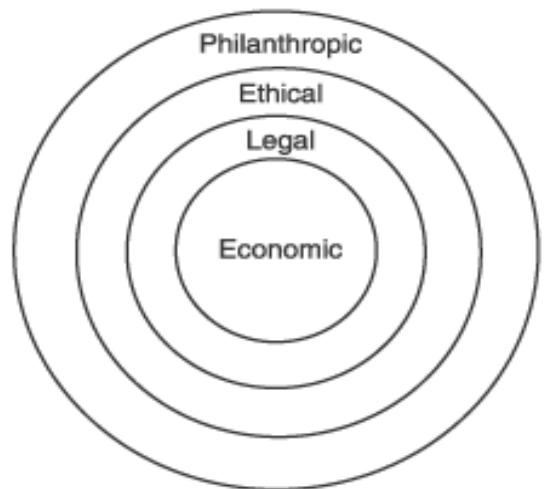

Fig-1:- Three models of corporate social responsibility

The next analysis have made up standards base line operations of companies has undertaken in its labor practices the Universal Declaration on Human Rights of the United Nations and aligns professional conduct with all of its protocols, in addition to international agreements approved by the UN and by the International Labor Organization (ILO) on social rights, as well as the OECD Guidelines for Multinational Companies. This is in line with Principle 1: Businesses should support and respect the protection of internationally proclaimed human rights. Principle 2:- Businesses must make sure that they are not complicit in human rights abuses. As assured by the interview and questionnaires response most of the companies haven't standardized selection processes and supplier control and follow-up mechanisms. This hinders the promotion among its stakeholder's observation and non-compliance with prevailing social and environmental norms, as well as not complies with all CSR constructs under the Global Compact. Principle 3: -Businesses should uphold freedom of association and the effective recognition of the right to collective bargaining. There is no open atmosphere of ongoing dialogue, the free association of its workers and considers this to be an inalienable right. Principle 4:- Businesses should support the elimination of all forms of forced and compulsory labor. There are some forms of forced labor and there is no initiatives aimed at elimination thereof. The company's internal norms, which are mandatory but not accessible for all employees, couldn't set down the company's recruitment policies and guidelines, as well as employee procedures and working conditions, all of which are intended to ensure work effectiveness, which 
couldn't gone through and a personal and professional life misbalance. Principle 5:- Businesses should support the abolition of child labor. Companies condemns all forms of child labor, are concerned for concerning minimum age. Furthermore, since there is no any in the stakeholders Social Responsibility Code, a mandatory requirement for Upstream and downstream developments could not applied. Principle 6:- Businesses should uphold the elimination of discriminatory practices in employment and occupation. Companies accept or abide by any action that entails discrimination of candidates in some instances any hiring process due to sex, nepotism and family background views, social background, and upholds a policy of equal pay for equal work. Companies policy on non-discrimination were not explicitly reflected in the Common Management council, which apply to the entire company and which are known by and mandatory for all stakeholders. Principle 7:- Businesses should support a precautionary approach to environmental challenges. Lack in Companies commitment to the environment and its awareness of today's environmental problems, as well as the development of a model based on sustainability, hasn't led to the company's business activity and structure being grounded in these values, which are integrated into its productive processes. Principle 8:- Businesses should undertake initiatives to promote greater environmental responsibility. Companies are not committed from its inception to sustainability and the struggle against climate change, integrates into the attainment of its business goals a policy focusing not only on its products and services contributing to sustainability, but also on achieving these goals in a sustainable manner, but contributing to economic progress, social equity and conservation of the environment is very eminent or null. Principle 9:- Businesses should encourage the development and diffusion of environmentallyfriendly technologies. In today's world there is a technology provider that applies innovative solutions for sustainable development. None of the companies activities couldn't conducted by the company through its five business units: Solar, Bioenergy, Environmental Services, Information Technologies, and Industrial Engineering and Construction, is aimed at developing and propagating environmentally-friendly technologies and enhancing energy efficiency. Principle 10:- Businesses should work against corruption in all of its forms, including coercion and bribery. It is well known that companies' most powerful tool for fighting corruption is its Code of Professional Conduct, which governs the acts and working relations of all stakeholders and non-compliance with this code may result in dissolution of the working relationship. This code not only prohibits all forms of corruption, including extortion and bribery, but rather demands the highest standards of honor and ethical conduct, and includes procedures for dealing with conflicts of interest between personal and professional relationships; requires suitable disclosure in the reports which wouldn't present on a regular basis to bodies of the stakeholders; Companies hasn't also promoted environmental awareness both inside and outside the company, in addition to participating in forums on sustainability. In general speaking our country in general in our case in particular the rules and regulation informs of basic laws or proclamations most of their parts can be considered as paper tiger because not only the written regulatory parts but also the firms feasibility and impact assessments documents couldn't reconsidered to assure the firm sustainability alignment with internal and external stakeholders' as per the promise able documents.

\section{Conclusion}

The past decades have seen an increase in attention to the role of business in society, with the concept of CSR taking up a big part of the discussion. Although much literature is dedicated to increase the understanding of CSR, empirical studies that address the driving factors and practices of CSR in developing countries remain scarce

The study assesses issues of CSR and their Practicing process in East Gojjam, considering both regional viewpoint and company-centered perspective. The study intends to gain a thorough understanding about how the concept of CSR forms and norms are integrated into 13 largest Factory found in East Gojjam Zone.

This study therefore, concludes that the Perceptions on CSR forms and norms in context of Ethiopia developed for centuries hasn't the potential to shape and determine the understanding and implementation of socially responsible actions. Such conclusion leads us that assume external environment, Social and economy context exerts huge influence and influenced on the way organizations CSR operations. Hence, the sympathy to the concept and practices of social responsibility in our case is still in its infant stage form and norm development.

\section{Recommendations}

* According to PDAC (2009) management system structure and requirements e-toolkit, we can recommend that every company must have to follow the following procedural series of activities to carry out the corporal social act in a responsible manner. These are:-

1. Define the strategy and make the commitment- Determine and understand the scope of commitment, define the strategy and direction, document your commitment in a social responsibility policy, and establish the governance framework for social responsibility.

2. Plan for social responsibility at a program level- Understand the requirements and standards of 
performance that apply to your activities, determine the social, environmental \& safety performance areas that are priorities for your organization, set performance objectives \& targets, and establish the action plans and programs to achieve objectives and targets.

3. Conduct project due diligence - Plan for social responsibility at project level, understand the requirements and standards of performance that apply to the project, identify the project risks, Assess risks, and establish a project plan.

4. Implement the Plan- Define the organizational structure for managing the activity, budget and make adequate resources to support achievement of performance goals, identify and put in place human resources to support the processes, conduct training to achieve strategy, policy commitments, and comply with binding requirements \& address significant risks, establish networks/ mechanisms to communicate internally, establish networks/ mechanisms to communicate externally, engage with stakeholders, put in place control measures that provide reasonable assurance that activities will achieve the defined objectives \& performance standards, establish mechanisms for data and document control, and prepare to respond to emergencies.

5. Monitor and Take Action to Improve Performance- Establish monitoring programs \& procedures, analyze monitoring results, establish mechanisms for incident and issue reporting, investigation and tracking(respond, investigate \& prevent), periodically verify performance (through internal or external audit), and establish a performance review process conducted by senior management, and

6. Report to Stakeholders.

* According to improving sustainability concept in developing countries Concentrate up on Sustainable Environmental Preservation and Management, which means corporate environmental sustainability and Pollution Prevention by applying:-

1. Modify production processes to emit less waste or emissions

2. Use non-toxic or less-toxic substances

3. Implement conservation techniques (less energy and water at your facility)

4. Reuse materials, such as production scrap or shop towels, rather than putting them into the waste stream

5. Reduce packaging

\section{References}

$>$ Aviva Geva (2008). Three Models of Corporate Social Responsibility: Interrelationships between Theory, Research, and Practice. https://doi.org/10.1111/j.1467-8594.2008.00311.x.

$>$ Brannick, T. (1997). An Over View of the Research Process. Dublin: Oak Tree Press. 1-30.

$>$ Bryman, A. and Bell, E. (2007). Business research methods. 2ed. Great Clarendon: Oxford University Press.

$>$ Carroll, A. B. (1991). The pyramid of corporate social responsibility: Toward the moral management of organizational stakeholders. Business Horizons, 34, 39-48.

> Carroll, A. B. (1999). The pyramid of corporate social responsibility: Toward the moral management of organizational stakeholders. Business Horizons, 34, 39-48.

$>$ Freeman, R. Edward. (1984). Strategic Management: A Stakeholder Perspective, Pitman Publishing Inc., Boston.

$>$ Johnson, H. L. (1971). Business in contemporary society: Framework and issues. Belmont, CA: Wadsworth.

$>$ Kothari, C.R. (2004) Research Methodology: Methods and Techniques. 2nd Edition, New Age International Publishers, New Delhi.

$>$ Merel Jasmijn van Egdom (2013). An Insight into Corporate Social Responsibility in Senegal. Master Thesis in Development Studies. Lund University, Department of Human Geography.

$>$ Nunnally, J. C (1978). Psychometric theory. McGrawHill. New York.

$>$ Organization for Economic Co-operation and Development [OECD] (2004, 2011).OECD Guidelines for Multinational Enterprises, OECD Publishing.

$>$ Pallant, J., (2016). SPSS Survival Manual, 6ed. Open University Press.

$>$ Robson, C. (2002). Real World Research: A Resource for Social Scientists and Practitioner-Researchers (2nd ed.). Blackwell Publishers Ltd, Oxford.

$>$ Sarkis, Joseph, Ni Na, and Qinghua Zhu (2011). Winds of Change: Corporate Social Responsibility in China, online: $\quad<$ http://iveybusiness journal.com/topics/social-responsibility/winds-of-change-corporate-socialresponsibility-in-china\#.

$>\mathrm{Su}$, Yongtong (2007). The Courage and Reasoning of Xiamenese, online: $<$ www.infzm.com/content/trs/raw/33291>.

$>$ Sultan Hassen ABDU (2015/16). Corporate Social Responsibility and its impact on profitability (A case study of Oil MNCs in Ethiopia). Master's studies. Andhra University, Department of Commerce \& 
Management Studies, Visakhapatnam, India.

$>$ United Nations Global Compacts. (Undated). The power of principles; Sustainability begins with a principles-based approach to doing business.

$>$ Visser, W. (2006). Revisiting Carroll's CSR Pyramid: An African Perspective; Corporate Citizenship in Developing Countries. Copenhagen Business School Press, Copenhagen.

$>$ Walton, C. C. (1967). Corporate social responsibilities. Belmont, CA: Wadsworth.

$>$ Williams, J. M., (2003). The craft of argument. (2nd ed.). New York: Long man Publishers.

$>$ Zaidatol Akmaliah Lope Pihie and Afsaneh Bagheri (2009). Entrepreneurship as a Career Choice: An Analysis of Entrepreneurial Self-Efficacy and Intention of University Students, 9(2), 338-346. 